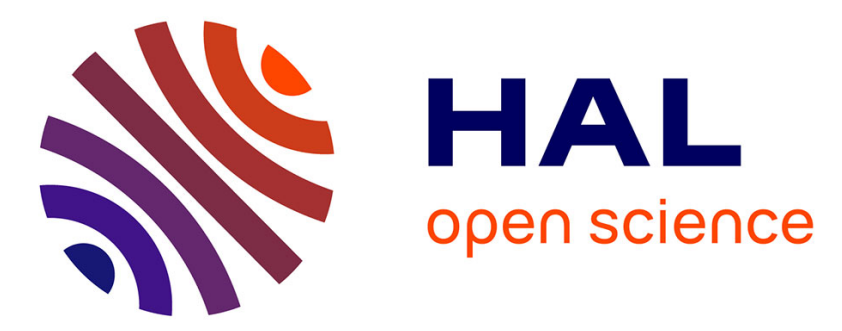

\title{
Synthesis, Crystal Structure and Ionic Conductivity of $\mathrm{Ag} 8 \mathrm{I} 2(\mathrm{CrO} 4) 3$ \\ Dragan Pitzschke
}

\section{To cite this version:}

Dragan Pitzschke. Synthesis, Crystal Structure and Ionic Conductivity of Ag8I2(CrO4)3. Journal of Inorganic and General Chemistry / Zeitschrift für anorganische und allgemeine Chemie, 2009, 635 (6-7), pp.926. 10.1002/zaac.200900050 . hal-00484133

\section{HAL Id: hal-00484133 https://hal.science/hal-00484133}

Submitted on 18 May 2010

HAL is a multi-disciplinary open access archive for the deposit and dissemination of scientific research documents, whether they are published or not. The documents may come from teaching and research institutions in France or abroad, or from public or private research centers.
L'archive ouverte pluridisciplinaire HAL, est destinée au dépôt et à la diffusion de documents scientifiques de niveau recherche, publiés ou non, émanant des établissements d'enseignement et de recherche français ou étrangers, des laboratoires publics ou privés. 


\section{Synthesis, Crystal Structure and Ionic Conductivity of $\mathrm{Ag}_{8} \mathrm{I}_{2}\left(\mathrm{CrO}_{4}\right)_{3}$}

\begin{tabular}{|r|l|}
\hline Journal: & Zeitschrift für Anorganische und Allgemeine Chemie \\
\hline Manuscript ID: & zaac.200900050 \\
\hline Wiley - Manuscript type: & Article \\
\hline $\begin{array}{r}\text { Date Submitted by the } \\
\text { Author: }\end{array}$ & 19-Jan-2009 \\
\hline Complete List of Authors: & $\begin{array}{l}\text { Pitzschke, Dragan; Max-Planck-Institut fuer Festkoerperforschung, } \\
\text { Chemie III }\end{array}$ \\
\hline Keywords: & Silver, Iodine, Chromate, Ionic conductivity, Crystal structure \\
\hline \multicolumn{2}{|l}{} \\
\hline
\end{tabular}

\section{\scholaroNE" \\ Manuscript Central}




\title{
ARTICLE
}

DOI: 10.1002/zaac.200((will be filled in by the editorial staff))

\section{Synthesis, Crystal Structure and Ionic Conductivity of $\operatorname{Ag}_{8} \mathbf{I}_{2}\left(\mathrm{CrO}_{4}\right)_{3}$}

\author{
Dragan Pitzschke, Jan Curda, and Martin Jansen*
}

Dedicated to Professor Gerd Meyer on the Occasion of his $60^{\text {th }}$ Birthday

Keywords: Silver; Iodine; Chromate; Ionic conductivity; Crystal structure

$\mathrm{Ag}_{8} \mathrm{I}_{2}\left(\mathrm{CrO}_{4}\right)_{3}$ has been synthesized by solid state reaction, starting from stoichiometric mixtures of $\mathrm{Ag}_{2} \mathrm{O}, \mathrm{AgI}$ and $\mathrm{Cr}_{2} \mathrm{O}_{3}$, at elevated oxygen pressures. The compound crystallizes in the hexagonal space group $P 6_{3} / m$, with the unit cell dimensions $\mathrm{a}=9.4474(4) \AA, \mathrm{c}=10.2672(4) \AA, \gamma=120^{\circ}, \mathrm{V}=793.61(6) \AA^{3}$, and $\mathrm{Z}=6$. The crystal structure was solved by direct methods and refined, basing on single crystal diffraction data (815 independent reflections, R1 $=2.45 \%)$. The structure is fully ordered. The $\mathrm{CrO}_{4}{ }^{2-}$ anions are arranged in the mode of an hep packing. Such a building principle is providing channels of face sharing octahedral voids. In the case of the title compound, there are three of such channels in the unit cell. Two of them accommodate two iodine atoms and one silver each, with iodine occupying the octahedral voids, and silver centering the triangular faces connecting the octahedra. Thus, for silver a trigonal bipyramidal coordination by three oxygen and two iodine ions result. In the third column of face sharing octahedra, silver is in the centre of the octahedra. The remaining silver atoms are located in the tetrahedral voids, between the $\mathrm{CrO}_{4}{ }^{2-}$ anions. According to the results of impedance measurements, $\mathrm{Ag}_{8} \mathrm{I}_{2}\left(\mathrm{CrO}_{4}\right)_{3}$ is a silver ion conductor. The compound shows an increase in the ionic conductivity in the temperature range from 25 to $175{ }^{\circ} \mathrm{C}$, and has a silver ion conductivity of $6.5 \times 10^{-4} \Omega^{-1} \mathrm{~cm}^{-1}$ at $30^{\circ} \mathrm{C}$. The activation energy for silver ion conduction is $0.21 \mathrm{eV}$, in the temperature range from 25 to $50^{\circ}$.

\author{
* Prof. Dr. M. Jansen \\ Fax: +49-711-689-1502 \\ E-mail: M.Jansen@fkf.mpg.de \\ Max-Planck-Institut für Festkörperforschung \\ Heisenbergstr. 1 \\ D-70569 Stuttgart, Germany
}

\section{Introduction}

Fast-ion electrolytes based on Ag-containing solids have been of interest in that they often show high ionic conductivity already at room temperature $[1,2]$. The search for new silver-ion conductors continues, considering various chemical systems, which include halides, chalcogenides and others [3-5]. The most famous members in this class of electrolytes are $\mathrm{AgI}$ and $\mathrm{RbAg}_{4} \mathrm{I}_{5}$. These materials are characterized by their high ionic conductivities, comparable to those observed in molten salts [5-7]. $\mathrm{RbAg}_{4} \mathrm{I}_{5}$ shows the highest ionic conductivity ever observed for a solid at ambient temperature $\left(\sigma(\mathrm{i})=0.27 \Omega^{-1} \mathrm{~cm}^{-1}\right)$ [8]. The structures of both, AgI and $\operatorname{RbAg}_{4} I_{5}$, have been studied thoroughly, in particular with respect to the disorder of the cation partial structure [7]. Among the good silver ion conductors, there is a class of compounds with compositelike topologies, containing silver iodide, and silver oxyacid salts, like $\mathrm{Ag}_{3} \mathrm{PO}_{4}, \mathrm{Ag}_{2} \mathrm{WO}_{4}, \mathrm{Ag}_{3} \mathrm{AsO}_{4}$ etc., at the same time [9-16]. The incorporation of silver ions in an immobile framework of complex oxoanions has proven to be an effective route to raise the silver ion conductivity. Recently, we expanded this field to composites containing AgI and silver selenates and tellurates, this way identifying $\mathrm{Ag}_{3} \mathrm{ITeO}_{4}, \mathrm{Ag}_{4} \mathrm{I}_{2} \mathrm{SeO}_{4}$ and $\mathrm{Ag}_{9} \mathrm{I}_{3}\left(\mathrm{SeO}_{4}\right)_{2}\left(\mathrm{IO}_{3}\right)_{2}$ as new silver solid electrolytes $[17,18]$. In the course of our structural investigation of crystalline analogues of the ion-conducting silver iodide silver oxyacid salt glasses, we have synthesized and characterized the compound $\mathrm{Ag}_{8} \mathrm{I}_{2}\left(\mathrm{CrO}_{4}\right)_{3}$.

\section{Experimental Section}

\section{Synthesis}

Starting materials for the preparation of $\mathrm{Ag}_{8} \mathrm{I}_{2}\left(\mathrm{CrO}_{4}\right)_{3}$ were $\mathrm{Ag}_{2} \mathrm{O}$ (freshly precipitated), $\mathrm{AgI}$ (Fluka, p.a.) and $\mathrm{Cr}_{2} \mathrm{O}_{3}$ (Fluka, $>98 \%$ ). The synthesis was performed by solid state reaction in stainless steel autoclaves at elevated oxygen pressures and temperatures. Stoichiometric amounts of the starting materials were intimately mixed and placed into gold tubes which were sealed from one side and mechanically (not gas-tight) closed from the other side. Polycrystalline samples of $\mathrm{Ag}_{8} \mathrm{I}_{2}\left(\mathrm{CrO}_{4}\right)_{3}$ were obtained under an oxygen pressure of $160 \mathrm{MPa}$, at a temperature of $450^{\circ} \mathrm{C}$ and a reaction time of 60 hours. The single crystals as obtained were of red-brown colour, and of irregular habitus. In order to prepare single crystals suitable for X-ray diffraction analysis, $0.2 \mathrm{ml} \mathrm{H}_{2} \mathrm{O}$ was added to the starting mixture as a mineraliser. The crystalline product was filtered off, washed with deionised water and dried in air. The compound is stable towards air and water.

The compositions of the samples were confirmed by EDX (Philips ESEM XL 30 equipped with an EDAX detector) analysis (Ag/I/Cr ratio $8.0: 1.83: 3.09$ ).

\section{$X$-ray investigations}

X-ray investigations on powder samples were performed using high-resolution X-ray powder diffraction data (D8, Bruker, $\mathrm{Cu} \mathrm{K} \alpha_{1}$ radiation from primary $\mathrm{Ge}(111)$ Johannson-type monochromator) at room temperature. The powder diffraction data were collected in the range of 5 to 90 degrees in 2 Theta. Experimental $d$ values and 
relative intensities are given in Table 1. The single crystal diffraction data were collected on a Bruker AXS Smart-CCD diffractometer (Mo K $\alpha$ radiation, graphite monochromator). The intensities were corrected for Lorentz, polarisation effects, and a face-indexed absorption correction was applied. The structure was solved and refined using the program packages SHELXS-97 and SHELXL-97 [19, 20]. The final refinement included anisotropic displacement parameters for all atoms. For the technical details of data acquisition and further crystallographic data see Tables $2-4$.

Table 1. Experimental X-ray powder data for $\mathrm{Ag}_{8} \mathrm{I}_{2}\left(\mathrm{CrO}_{4}\right)_{3}$ with d $>1.5 \AA(I>1 \%)$.

\begin{tabular}{|c|c|c|c|c|c|c|c|c|c|c|c|c|c|c|}
\hline$d_{\text {obs }} / \AA$ & $I / \%$ & $h$ & $k l$ & $l$ & $d_{\mathrm{obs}} / \AA$ & $I / \%$ & $h$ & $k \quad l$ & & $d_{\mathrm{obs}} / \AA$ & $I / \%$ & $h$ & $k \quad l$ & $l$ \\
\hline 8.1816 & 4.2 & 0 & 10 & 0 & 2.2157 & 2.7 & 3 & 11 & 1 & 1.7106 & 5.5 & 2 & 15 & 5 \\
\hline 6.3985 & 2.7 & 0 & 11 & 1 & 2.1742 & 1.4 & 0 & 24 & 4 & 1.7106 & 5.5 & 1 & 25 & 5 \\
\hline 5.1336 & 7.8 & 0 & 02 & 2 & 2.1456 & 1.6 & 2 & & 2 & 1.6863 & 1.9 & 1 & & 2 \\
\hline 4.2913 & 1.8 & 1 & 11 & 1 & 2.0755 & 2.1 & 1 & 32 & 2 & 1.6863 & 1.9 & 4 & 12 & 2 \\
\hline 3.8003 & 1.5 & 0 & 21 & 1 & 2.0800 & 2.1 & 3 & & 2 & 1.6457 & 3.8 & 3 & & 3 \\
\hline 3.4760 & 6.3 & 1 & 12 & 2 & 2.0454 & 3.6 & 0 & 40 & 0 & 1.6457 & 3.8 & 2 & 33 & 3 \\
\hline 3.1993 & 8.3 & 0 & 22 & 2 & 2.0060 & 1.7 & 0 & 41 & 1 & 1.6363 & 6.5 & 0 & 5 & 0 \\
\hline 3.1600 & 5.8 & 0 & 13 & 3 & 1.9917 & 1.2 & 0 & 15 & 5 & 1.6159 & 1.2 & 0 & 5 & 1 \\
\hline 3.0924 & 1.9 & 1 & 20 & 0 & 1.9439 & 38.8 & 2 & 23 & 3 & 1.6089 & 24.3 & 1 & 1 & 6 \\
\hline 3.0924 & 1.9 & 2 & 10 & 0 & 1.9001 & 5.1 & 0 & 42 & 2 & 1.5996 & 2.7 & 0 & 4 & 4 \\
\hline 2.9610 & 7.1 & 1 & 21 & 1 & 1.8912 & 12.4 & 1 & 33 & 3 & 1.5800 & 18.1 & 4 & 13 & 3 \\
\hline 2.9610 & 7.1 & 2 & 11 & 1 & 1.8912 & 12.4 & 3 & 13 & 3 & 1.5800 & 18.1 & 1 & 43 & 3 \\
\hline 2.7714 & 68.0 & 1 & 13 & 3 & 1.8832 & 8.4 & 1 & 15 & 5 & 1.5787 & 1.0 & 0 & 2 & 6 \\
\hline 2.7272 & 100.0 & 0 & 30 & 0 & 1.8770 & 2.1 & 3 & 20 & 0 & 1.5700 & 31.8 & 3 & 3 & 0 \\
\hline 2.6498 & 1.1 & 1 & 22 & 2 & 1.8770 & 2.1 & 2 & 30 & 0 & 1.5590 & 10.8 & 0 & 52 & 2 \\
\hline 2.6489 & 1.1 & 2 & 12 & 2 & 1.8691 & 14.9 & 0 & 3 & 4 & 1.5600 & 1.6 & 3 & 3 & 1 \\
\hline 2.6249 & 14.7 & 0 & 23 & 3 & 1.8464 & 3.2 & 3 & 21 & 1 & 1.5496 & 6.5 & 2 & 25 & 5 \\
\hline 2.5668 & 4.3 & 0 & 04 & 4 & 1.8464 & 3.2 & 2 & 3 & 1 & 1.5462 & 4.1 & 4 & 20 & 0 \\
\hline 2.4085 & 38.1 & 0 & 32 & 2 & 1.7854 & 4.4 & 1 & 40 & 0 & 1.5462 & 4.1 & 2 & 4 & 0 \\
\hline 2.3618 & 6.6 & 2 & 20 & 0 & 1.7854 & 4.4 & 4 & 10 & 0 & 1.5289 & 5.9 & 4 & 2 & 1 \\
\hline 2.3017 & 5.9 & 2 & 21 & 1 & 1.7629 & 8.2 & 3 & 22 & 2 & 1.5289 & 5.9 & 2 & 4 & 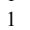 \\
\hline 2.2945 & 9.8 & 2 & 13 & 3 & 1.7629 & 8.2 & 2 & 3 & 2 & 1.5226 & 4.7 & 1 & 3 & 5 \\
\hline 2.2945 & 9.8 & 1 & 23 & 3 & 1.7590 & 1.3 & 1 & 4 & 1 & 1.5226 & 4.7 & 3 & 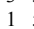 & 5 \\
\hline 2.2692 & 3.9 & 1 & 30 & 0 & 1.7590 & 1.3 & 4 & 1 & 1 & 1.5200 & 5.3 & 3 & 2 & 4 \\
\hline 2.2692 & 3.9 & 3 & 10 & 0 & 1.7557 & 4.6 & 0 & 4 & 3 & 1.5151 & 5.3 & 2 & 3 & 7 \\
\hline 2.2553 & 28.7 & 1 & 14 & 4 & 1.7400 & 23.3 & 2 & 2 & 4 & 1.5053 & 18.4 & 3 & 3 & 2 \\
\hline 2.2157 & 2.7 & 1 & 31 & 1 & 1.7112 & 4.8 & 0 & 0 & 6 & 1.5000 & 2.5 & 1 & 2 & 6 \\
\hline
\end{tabular}

\section{Impedance Spectroscopy}

Ion-blocking gold electrodes were used to measure ionic conductivity of compact samples (diameter $6 \mathrm{~mm}$, thickness 0.85 $\mathrm{mm}$, pressed with $200 \mathrm{MPa}$ ). The samples were placed into a quartz glass cell in air during the measurement [21]. The temperature dependent ac impedance spectra were measured with an Novocontrol Alpha-A 4.2 Analyzer combined with the impedance interface ZG4 in a 2-wire arrangement in the frequency range of $v=1 \mathrm{~Hz}$ to $v=20 \mathrm{MHz}$. Measurements and data recording were performed with the WinDeta program [22]. The bulk conductivity was determined by non linear mean square deviation curve fitting of the impedance spectrum using the WinFit program [23].

\section{Results and Discussion}

\section{Crystal Structure}

As a characteristic feature, $\mathrm{Ag}_{8} \mathrm{I}_{2}\left(\mathrm{CrO}_{4}\right)_{3}$ exhibits the uncommon coexistence of $\mathrm{I}^{-}$and $\mathrm{CrO}_{4}{ }^{2-}$ ions, within the same compound. The aesthetically appealing crystal structure (see Figure 1) contains one crystallographically independent site for chromium, which is in fairly regular tetrahedral coordination by four oxygen atoms. The $\mathrm{Cr}-\mathrm{O}$ bond distances cover the range from $1.634-1.674 \AA$, and thus are in good agreement with typical values found for chromates(VI) $[25,26]$. The average $\mathrm{O}-\mathrm{Cr}-\mathrm{O}$ angle of $109.5^{\circ}$ is very close to the regular tetrahedral value and only the $\mathrm{O} 2-\mathrm{Cr} 1-\mathrm{O} 2$ angle $\left(112.4^{\circ}\right)$ differs more than $2^{\circ}$ from this ideal case. The isolated $\mathrm{CrO}_{4}{ }^{2-}$ tetrahedra are arranged in the sense of an hcp packing scheme (Fig.1 and 2).
Table 2. Details of the data collection and selected refinement results for $\mathrm{Ag}_{8} \mathrm{I}_{2}\left(\mathrm{CrO}_{4}\right)_{3}$.

\begin{tabular}{|c|c|}
\hline & $\mathrm{Ag}_{8} \mathrm{I}_{2}\left(\mathrm{CrO}_{4}\right)_{3}$ \\
\hline Crystal system & hexagonal \\
\hline Formula weight $/ \mathrm{g} \mathrm{mol}^{-1}$ & 488.25 \\
\hline \multicolumn{2}{|c|}{ Lattice constants (from powder) } \\
\hline $\mathrm{a} / \AA$ & $9.4474(4)$ \\
\hline $\mathrm{c} / \AA$ & $10.2672(4)$ \\
\hline$\gamma /{ }^{\circ}$ & 120 \\
\hline $\mathrm{V} / \AA^{3}$ & $793.61(6)$ \\
\hline Space group & $P 6_{3} / m$ \\
\hline $\mathrm{Z}$ & 6 \\
\hline Calc. density $/ \mathrm{g} \mathrm{cm}^{-3}$ & 6.130 \\
\hline Crystal shape, color & Polyhedra, red-brown \\
\hline Diffractometer & Bruker AXS Smart-CCD \\
\hline Monochromator & Graphite \\
\hline Wavelength / $\AA$ & 0.71073 \\
\hline Temperature / K & 293(2) \\
\hline 2 Theta range $/{ }^{\circ}$ & $5-60$ \\
\hline Index range & $-13 \leq \mathrm{h} \leq 13$ \\
\hline Absorption correction & Program SADABS [24] \\
\hline Reflections collected & 9941 \\
\hline Independent reflections & 815 \\
\hline$\mu / \mathrm{mm}^{-1}$ & 15.54 \\
\hline $\mathrm{F}(000)$ & 1300 \\
\hline parameters & 44 \\
\hline Goodness-of-fit on $\mathrm{F}^{2}$ & 1.126 \\
\hline $\mathrm{R} 1$ for $\mathrm{F}_{0}>4 \sigma\left(\mathrm{F}_{0}\right)$ & 2.45 \\
\hline wR2 all reflections & 5.92 \\
\hline $\mathrm{wR} 2$ for $\mathrm{F}_{0}>4 \sigma\left(\mathrm{F}_{0}\right)$ & 6.02 \\
\hline$\Delta \rho /\left(\mathrm{e} / \AA^{3}\right)$ & $1.158 /-1.488$ \\
\hline Deposition no. [28] & CSD - 419833 \\
\hline
\end{tabular}

In accordance with the number of six $\mathrm{CrO}_{4}{ }^{2-}$ anions per unit cell, there are six face sharing octahedral vacancies in this packing, which generate three columns of face sharing octahedra. Two of the resulting channels extending along [001] accommodate two iodine and one silver atom each, with iodine occupying the octahedral voids. The triangular faces connecting the octahedra in these latter rods are occupied by $\mathrm{Ag}^{+}(3+2$ coordination). The octahedral sites of the third column, passing the origin, are solely occupied by silver ions. Because of the larger diameter of $\mathrm{I}^{-}$as compared to $\mathrm{Ag}^{+}$the former two columns are expanded. The remaining silver atoms are occupying all the tetrahedral voids of the hcp arrangement of the $\mathrm{CrO}_{4}{ }^{2-}$ anions.

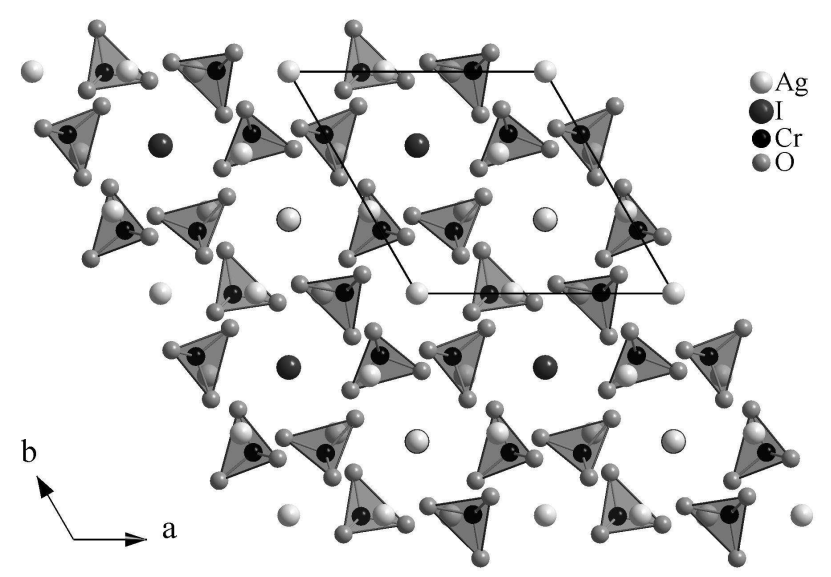

Figure 1. View at the crystal structure of $\mathrm{Ag}_{8} \mathrm{I}_{2}\left(\mathrm{CrO}_{4}\right)_{3}$ along [001]. 


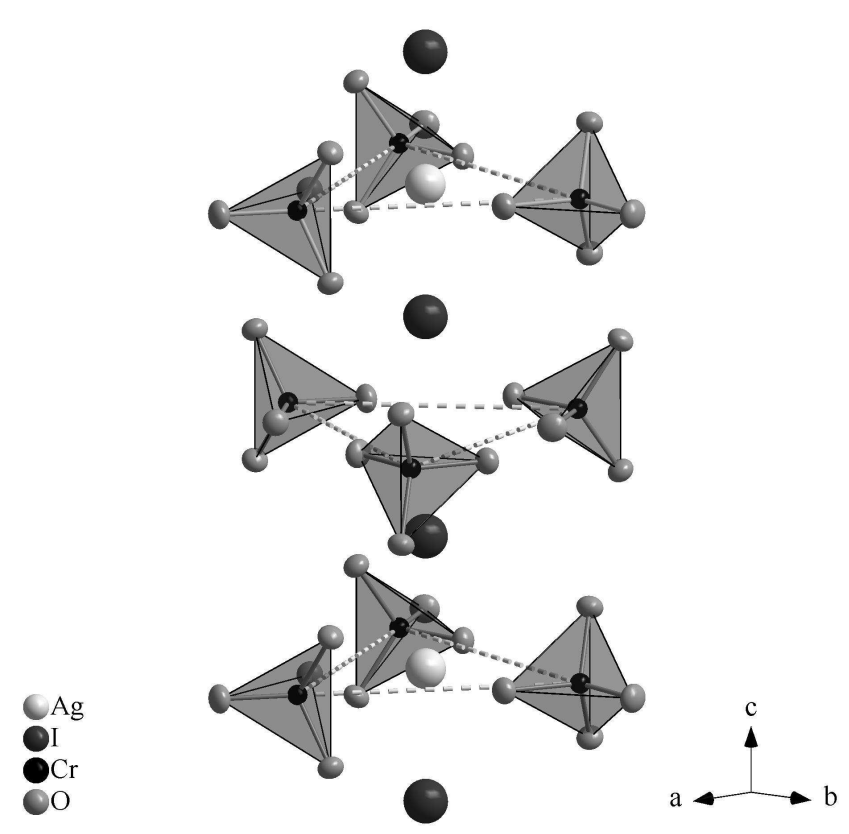

Figure 2. "Channel" of face sharing octahedral voids of the chromate hcp packing, occupied by iodide and silver.

Table 3. Atomic coordinates and equivalent isotropic displacement parameters $\mathrm{U}_{e q}{ }^{\text {a) }}$ for $\mathrm{Ag}_{8} \mathrm{I}_{2}\left(\mathrm{CrO}_{4}\right)_{3}$.

\begin{tabular}{cccccc}
\hline Atom & $\begin{array}{c}\text { Wyckoff } \\
\text { position }\end{array}$ & $x / a$ & $y / b$ & $z / c$ & $\mathrm{U}_{\mathrm{eq}} / \AA^{2}$ \\
\hline $\mathrm{Ag}(1)$ & $2 c$ & 0.6667 & 0.3333 & -0.2500 & $0.0335(2)$ \\
$\mathrm{Ag}(2)$ & $12 i$ & $0.6291(1)$ & $-0.0011(1)$ & $0.0736(1)$ & $0.0324(1)$ \\
$\mathrm{Ag}(3)$ & $2 b$ & 0.0000 & 0.0000 & 0.0000 & $0.0266(2)$ \\
$\mathrm{I}(1)$ & $4 f$ & 0.6667 & 0.3333 & $0.0236(1)$ & $0.0265(1)$ \\
$\mathrm{Cr}(1)$ & $6 h$ & $0.7199(1)$ & $0.0038(1)$ & -0.2500 & $0.0190(2)$ \\
$\mathrm{O}(1)$ & $6 h$ & $0.5644(5)$ & $0.0412(5)$ & -0.2500 & $0.0291(8)$ \\
$\mathrm{O}(2)$ & $12 i$ & $0.8289(4)$ & $0.0848(5)$ & $-0.1153(3)$ & $0.0291(6)$ \\
$\mathrm{O}(3)$ & $6 h$ & $0.6508(6)$ & $-0.1930(5)$ & -0.2500 & $0.0335(9)$ \\
\hline a] $\mathrm{U}_{\mathrm{eq}}=1 / 3\left[\mathrm{U}_{33}+4 / 3\left(\mathrm{U}_{11}+\mathrm{U}_{22}-\mathrm{U}_{12}\right)\right]$ & &
\end{tabular}

The structure thus corresponds in part to the anti-TiI ${ }_{3}$ structure type, with $\mathrm{CrO}_{4}{ }^{2-}$ anions in place of the iodine atoms. The coordination environment of the silver atoms follows from their positions within the hcp of the chromate(VI) anions, at the triangular faces, and the tetrahedral and octahedral voids. Positioned at a center of symmetry, the coordination of Ag1 can be well described as a trigonal bipyramid with three oxygen atoms in the equatorial plane and two iodine atoms in apical positions, with $\mathrm{Ag}-\mathrm{O}$ bonds of $2.426 \AA$ and apical $\mathrm{Ag}-\mathrm{I}$ distances of $2.809 \AA$, respectively. The corresponding angles are ideal $\left(90.0,120.0\right.$ and $\left.180.0^{\circ}\right)$, indicating the perfect trigonal bipyramidal environment of Ag1 (Fig. 3). Ag2 exhibits a $\psi$ trigonal-bipyramidal coordination in respect of the oxygen atoms, with bond lengths in a narrow range between 2.384 and $2.541 \AA$. At some longer distances of 3.042 and $3.144 \AA$ there are two additional bonds to iodine atoms, forming together with the oxygen atoms a heavily distorted octahedral surrounding of $\mathrm{Ag} 2$ (angles: 77.2 to $150.9^{\circ}$ ). The X-ray single-crystal structure determination establishes that the coordination sphere of Ag3 simply consists of six oxygen atoms, forming a moderately distorted octahedron with equidistant $\mathrm{Ag}-\mathrm{O}$ bond lengths of $2.439 \AA$ and angles between 81.6 and $180.0^{\circ}$ (Fig. 3).
Table 4. Selected interatomic distances $/ \AA$ and angles $/{ }^{\circ}$ for $\mathrm{Ag}_{8} \mathrm{I}_{2}\left(\mathrm{CrO}_{4}\right)_{3}$. Estimated standard deviations are given in parentheses.

\begin{tabular}{lllll}
\hline $\mathrm{Ag}(1)-\mathrm{O}(1)$ & $2.426(4)$ & {$[3 \times]$} & $\mathrm{Ag}(1)-\mathrm{I}(1)$ & $2.809(1)$ \\
$\mathrm{Ag}(2)-\mathrm{O}(1)$ & $2.465(3)$ & $\mathrm{Ag}(2)-\mathrm{I}(1)$ & $3.042(1)$ \\
$\mathrm{Ag}(2)-\mathrm{O}(2)$ & $2.384(3)$ & $\mathrm{Ag}(2)-\mathrm{I}(1)$ & $3.144(1)$ \\
$\mathrm{Ag}(2)-\mathrm{O}(2)$ & $2.541(3)$ & $\mathrm{Ag}(2)-\mathrm{Ag}(2)$ & $2.880(1)$ \\
$\mathrm{Ag}(2)-\mathrm{O}(3)$ & $2.412(3)$ & $\mathrm{Cr}(1)-\mathrm{O}(1)$ & $1.674(4)$ \\
$\mathrm{Ag}(3)-\mathrm{O}(2)$ & $2.439(3)$ & {$[6 \times]$} & $\mathrm{Cr}(1)-\mathrm{O}(2)$ & $1.664(3)$ \\
$\mathrm{Ag}(1)-\mathrm{I}(1)$ & $2.809(1)$ & $\mathrm{Cr}(1)-\mathrm{O}(3)$ & $1.634(4)$ \\
& & & & \\
$\mathrm{O}(2)-\mathrm{Cr}(1)-\mathrm{O}(1)$ & $108.1(1)$ & {$[2 \times]$} & $\mathrm{O}(2)-\mathrm{Ag}(3)-\mathrm{O}(2)$ & $81.6(1)[6 \times]$ \\
$\mathrm{O}(2)-\mathrm{Cr}(1)-\mathrm{O}(2)$ & $112.4(2)$ & $\mathrm{O}(1)-\mathrm{Ag}(1)-\mathrm{I}(1)$ & $90.0 \quad[6 \times]$ \\
$\mathrm{O}(3)-\mathrm{Cr}(1)-\mathrm{O}(1)$ & $110.3(2)$ & $\mathrm{O}(1)-\mathrm{Ag}(2)-\mathrm{I}(1)$ & $88.6(1)$ \\
$\mathrm{O}(3)-\mathrm{Cr}(1)-\mathrm{O}(2)$ & $109.1(1)$ & {$[2 \times]$} & $\mathrm{O}(1)-\mathrm{Ag}(2)-\mathrm{I}(1)$ & $81.9(1)$ \\
$\mathrm{O}(1)-\mathrm{Ag}(1)-\mathrm{O}(1)$ & $120.0(1)$ & {$[3 \times]$} & $\mathrm{O}(2)-\mathrm{Ag}(2)-\mathrm{I}(1)$ & $81.8(1)$ \\
$\mathrm{O}(1)-\mathrm{Ag}(2)-\mathrm{O}(2)$ & $170.4(1)$ & $\mathrm{O}(2)-\mathrm{Ag}(2)-\mathrm{I}(1)$ & $82.1(1)$ \\
$\mathrm{O}(2)-\mathrm{Ag}(2)-\mathrm{O}(1)$ & $108.5(1)$ & $\mathrm{O}(2)-\mathrm{Ag}(2)-\mathrm{I}(1)$ & $102.9(1)$ \\
$\mathrm{O}(2)-\mathrm{Ag}(2)-\mathrm{O}(2)$ & $80.6(1)$ & $\mathrm{O}(2)-\mathrm{Ag}(2)-\mathrm{I}(1)$ & $150.9(1)$ \\
$\mathrm{O}(2)-\mathrm{Ag}(2)-\mathrm{O}(3)$ & $82.5(1)$ & $\mathrm{O}(3)-\mathrm{Ag}(2)-\mathrm{I}(1)$ & $78.6(1)$ \\
$\mathrm{O}(3)-\mathrm{Ag}(2)-\mathrm{O}(1)$ & $77.2(1)$ & $\mathrm{O}(3)-\mathrm{Ag}(2)-\mathrm{I}(1)$ & $148.4(8)$ \\
$\mathrm{O}(3)-\mathrm{Ag}(2)-\mathrm{O}(2)$ & $101.5(1)$ & $\mathrm{I}(1)-\mathrm{Ag}(1)-\mathrm{I}(1)$ & $180.0 \quad[6 \times]$ \\
$\mathrm{O}(2)-\mathrm{Ag}(3)-\mathrm{O}(2)$ & $98.4(1)$ & {$[6 \times]$} & $\mathrm{I}(1)-\mathrm{Ag}(2)-\mathrm{I}(1)$ & $124.5(1)$ \\
$\mathrm{O}(2)-\mathrm{Ag}(3)-\mathrm{O}(2)$ & $180.0(1)$ & & \\
\hline
\end{tabular}

Similar silver coordination numbers and the corresponding bonding distances have been frequently observed in various silveroxide and silveriodine materials [7-18]. The shortest $\mathrm{Ag}-\mathrm{Ag}$ distance observed is 2.880(1) $\AA$ (Ag2-Ag2). This is shorter than the sum of the van-derWaals contacts of $3.4 \AA$ and comparable to the interatomic distance in metallic silver $(2.89 \AA)$. Such short silver-silver distances have been frequently observed in silver rich oxides [27]. The remaining $\mathrm{Ag}-\mathrm{Ag}$ distances are between 3.043 and $3.812 \AA$.

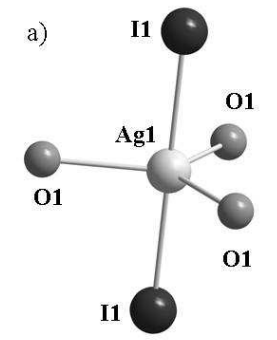

b)
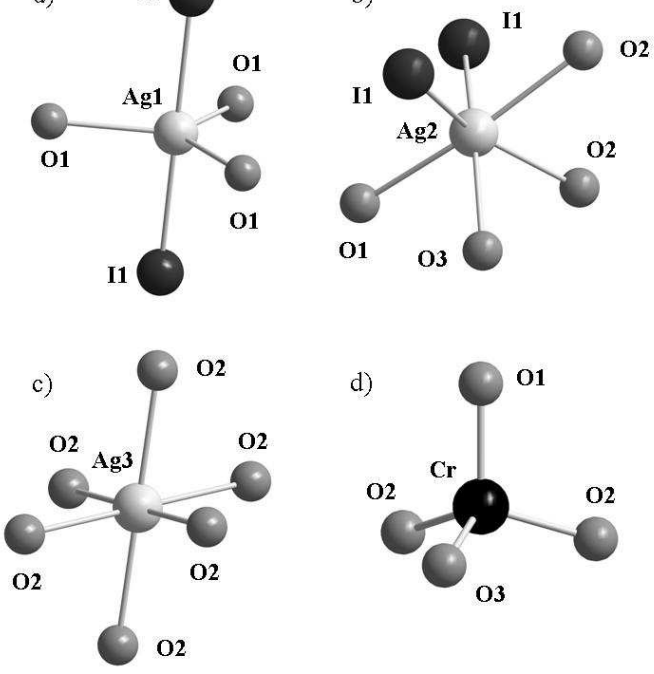

d)

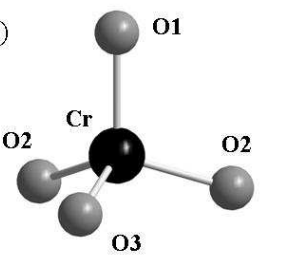

Figure 3. Coordination environments of $\mathrm{Cr}$ and $\mathrm{Ag}$ in $\mathrm{Ag}_{8} \mathrm{I}_{2}\left(\mathrm{CrO}_{4}\right)_{3}$.

\section{Ionic conductivity}

The temperature dependence of the ionic conductivity for $\mathrm{Ag}_{8} \mathrm{I}_{2}\left(\mathrm{CrO}_{4}\right)_{3}$ was investigated by impedance spectroscopy. 
The Arrhenius plot of the temperature-dependent ionic conductivity is displayed in Fig. 4. The corresponding activation energy $\left(E_{a}\right)$ has been derived from the slopes of the conductivity curves by using the Arrhenius equation, and the conductivities at selected temperatures are listed in Table 5. Between RT and $175{ }^{\circ} \mathrm{C}$, the conductivity of $\mathrm{Ag}_{8} \mathrm{I}_{2}\left(\mathrm{CrO}_{4}\right)_{3}$ increases gradually from $6.5 \times 10^{-4}$ to $5.7 \times 10^{-}$ $2 \Omega^{-1} \mathrm{~cm}^{-1}$ in two steps. The curve of the temperaturedependent ionic conductivity can be divided into two different steps. During the first step between RT and $120^{\circ} \mathrm{C}$ a flat increase is noticeable. Within this range, the conductivity increases by one order of magnitude. Between 120 and $175{ }^{\circ} \mathrm{C}$ a jump occurs, with a further increase by one order of magnitude in the conductivity. During the heating process, no colour change was observable. The calculated activation energies by applying the Arrhenius model yield similar values for the measurements in both, the heating and cooling mode (Table 5).

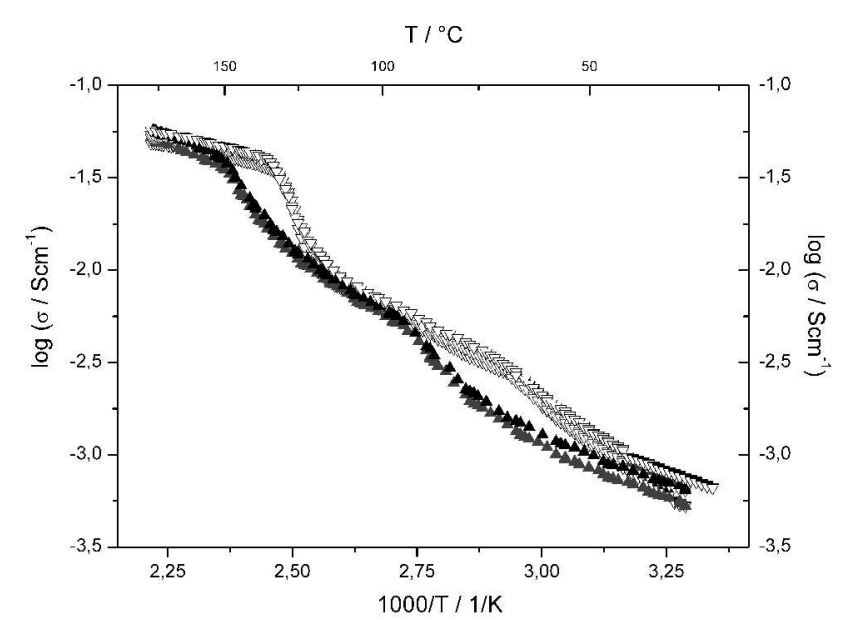

Figure 4. Temperature dependence of bulk ionic conductivity for $\mathrm{Ag}_{8} \mathrm{I}_{2}\left(\mathrm{CrO}_{4}\right)_{3}$. Filled symbols represent heating, open symbols cooling.

Table 5. Ionic conductivities $(\sigma)$ and activation energy $\left(E_{a}\right)$ for $\mathrm{Ag}_{8} \mathrm{I}_{2}\left(\mathrm{CrO}_{4}\right)_{3}$.

\begin{tabular}{lll}
\hline & $\sigma / \Omega^{-1} \mathrm{~cm}^{-1}$ & $E_{a} / \mathrm{eV}$ \\
\hline \multirow{3}{*}{ heating } & $30^{\circ} \mathrm{C}: 6.5 \times 10^{-4} \Omega^{-1} \mathrm{~cm}^{-1}$ & $25-50^{\circ} \mathrm{C}: 0.21$ \\
& $110^{\circ} \mathrm{C}: 8.3 \times 10^{-3} \Omega^{-1} \mathrm{~cm}^{-1}$ & $90-120^{\circ} \mathrm{C}: 0.36$ \\
& $175^{\circ} \mathrm{C}: 5.7 \times 10^{-2} \Omega^{-1} \mathrm{~cm}^{-1}$ & $150-175^{\circ} \mathrm{C}: 0.25$ \\
\hline \multirow{3}{*}{ cooling } & $30^{\circ} \mathrm{C}: 7.3 \times 10^{-4} \Omega^{-1} \mathrm{~cm}^{-1}$ & $25-50^{\circ} \mathrm{C}: 0.25$ \\
& $110^{\circ} \mathrm{C}: 8.7 \times 10^{-3} \Omega^{-1} \mathrm{~cm}^{-1}$ & $90-120^{\circ} \mathrm{C}: 0.36$ \\
& $175^{\circ} \mathrm{C}: 5.6 \times 10^{-2} \Omega^{-1} \mathrm{~cm}^{-1}$ & $150-175^{\circ} \mathrm{C}: 0.15$ \\
\hline
\end{tabular}

The change in conductivity values upon the heating and cooling cycles is completely reversible. In order to check for possible phase transformations occurring during the heating process, powder and single crystalline samples of $\mathrm{Ag}_{8} \mathrm{I}_{2}\left(\mathrm{CrO}_{4}\right)_{3}$ were investigated on respective diffractometers at a temperature of 120 and $180^{\circ} \mathrm{C}$. Unfortunately, the crystallinity of the samples decreased significantly upon heating, presumably due to the melting of the silver sublattice. Therefore no conclusive evidence for a structural phase transitions to occur, and being the reason for the steep increase in conductivity, was obtained.

\section{Conclusions}

The new solid electrolyte $\mathrm{Ag}_{8} \mathrm{I}_{2}\left(\mathrm{CrO}_{4}\right)_{3}$ is showing pure silver ionic conductivity as high as $6.5 \times 10^{-4} \Omega^{-1} \mathrm{~cm}^{-1}$ at RT, and an activation energy for conduction of $0.21 \mathrm{eV}$ between 25 and $50{ }^{\circ} \mathrm{C}$. In analogy to $\mathrm{Ag}_{4} \mathrm{I}_{2} \mathrm{SeO}_{4}$, also $\mathrm{Ag}_{8} \mathrm{I}_{2}\left(\mathrm{CrO}_{4}\right)_{3}$ is consisting of isolated building units. In contrast to former silver iodine materials the jump in the absolute value of the ionic conductivity is only moderate in $\mathrm{Ag}_{8} \mathrm{I}_{2}\left(\mathrm{CrO}_{4}\right)_{3}$.

\section{Acknowledgments}

We thank Dr. J. Nuss for collecting of the single crystal X-ray data, and Güliz Cakmak for recording the ionic conductivity measurements.

[1] S. Hull, Rep. Prog. Phys. 2004, 67, 1233.

[2] K. Funke, Prog. Solid State. Chem. A 1976, 11, 345.

[3] T. Nilges, S. Lange, Z. Anorg. Allg. Chem. 2005, 631, 3002.

[4] S. Lange, T. Nilges, Chem. Mater. 2006, 18, 2538.

[5] R. J. Cava, F. Reidinger, B. J. Wuensch, Solid State Comm. 1977, 24, 411.

[6] S. Geller, Science 1967, 157, 310.

[7] K. Funke, R. D. Banhatti, D. Willmer, R. Dinnebier A. Fitch, M. Jansen, J. Phys. Chem. A 2006, 110, 3010.

[8] S. Geller, Phys. Rev. B 1967, 14, 4345.

[9] T. Takahashi, S. Ikeda, O. Yamamoto, J. Electrochem. Soc. 1972, 119, 477.

[10] J. D. Garrett, J. E. Greedan, R. Faggiani, S. Carbotte, I. D. Brown, J. Solid State Chem. 1982, 42, 183.

[11] M. Sayer, S. L. Segel, J. Noad, J. Corey, T. Boyle, R. D. Heyding, A. Mansingh, J. Solid State Chem. 1982, 42, 191.

[12] S. Adams, A. Preusser, Acta Crystallogr. 1999, C55, 1741.

[13] T. Takahashi, S. Ikeda, O. Yamamoto, J. Electrochem. Soc. 1973, 120, 647.

[14] L. Y. Y. Chan, S. Geller, J. Solid State Chem. 1977, 21, 331.

[15] B. Scrosati, F. Papaleo, G. Pistoia, M. Lazzari, J. Electrochem. Soc. 1975, 122, 339.

[16] A. Magistris, G. Chiodelli, G. V. Campari, Z. Naturforsch. 1976, 31a, 974 .

[17] D. Pitzschke, J. Curda, G. Cakmak, M. Jansen, Z. Anorg. Allg. Chem. 2008, 634, 1071.

[18] D. Pitzschke, J. Curda, G. Cakmak, M. Jansen, Z. Anorg. Allg. Chem. 2008, 634, 1907.

[19] G.M. Sheldrick, SHELXS-97, Universität Göttingen, 1997.

[20] G.M. Sheldrick, SHELXL-97, Universität Göttingen, 1997.

[21] U. Köhler, Thesis, Univ. Hannover, 1987.

[22] Novocontrol GmbH, WinDeta V4.5, Hundsangen 1995-2003.

[23] Novocontrol GmbH, WinFit V2.9, Hundsangen 1996.

[24] G.M. Sheldrick, SADABS 2.10, Bruker AXS Inc., Madison, WI, 2003.

[25] J. Curda, E.-M. Peters, W. Klein, M. Jansen, Z. Kristallogr. NCS 2001, 216, 180.

[26] M. L. Hackert, R. A. Jacobson, J. Solid State Chem. 1971, 3, 364.

[27] M. Jansen, Angew. Chem. 1987, 99, 1136; Angew. Chem. Int. Ed. 1987, 26, 1098 . 
[28] Further details of the crystal structure investigation may be obtained from the Fachinformationszentrum (FIZ) Karlsruhe, D-76344 Eggenstein-Leopoldshafen, Germany, on quoting the depository number CSD-419833 for $\mathrm{Ag}_{8} \mathrm{I}_{2}\left(\mathrm{CrO}_{4}\right)_{3}$ (http://www.fiz-karlsruhe.de/).

Received: ((will be filled in by the editorial staff)) Published online: ((will be filled in by the editorial staff)) 


1
2
3
4
5
6
7
8
9
10
11
12
13
14
15
16
17
18
19
20
21
22
23
24
25
26
27
28
29
30
31
32
33
34
35
36
37
38
39
40
41
42
43
40
45
49
50
51
52
53
55
50

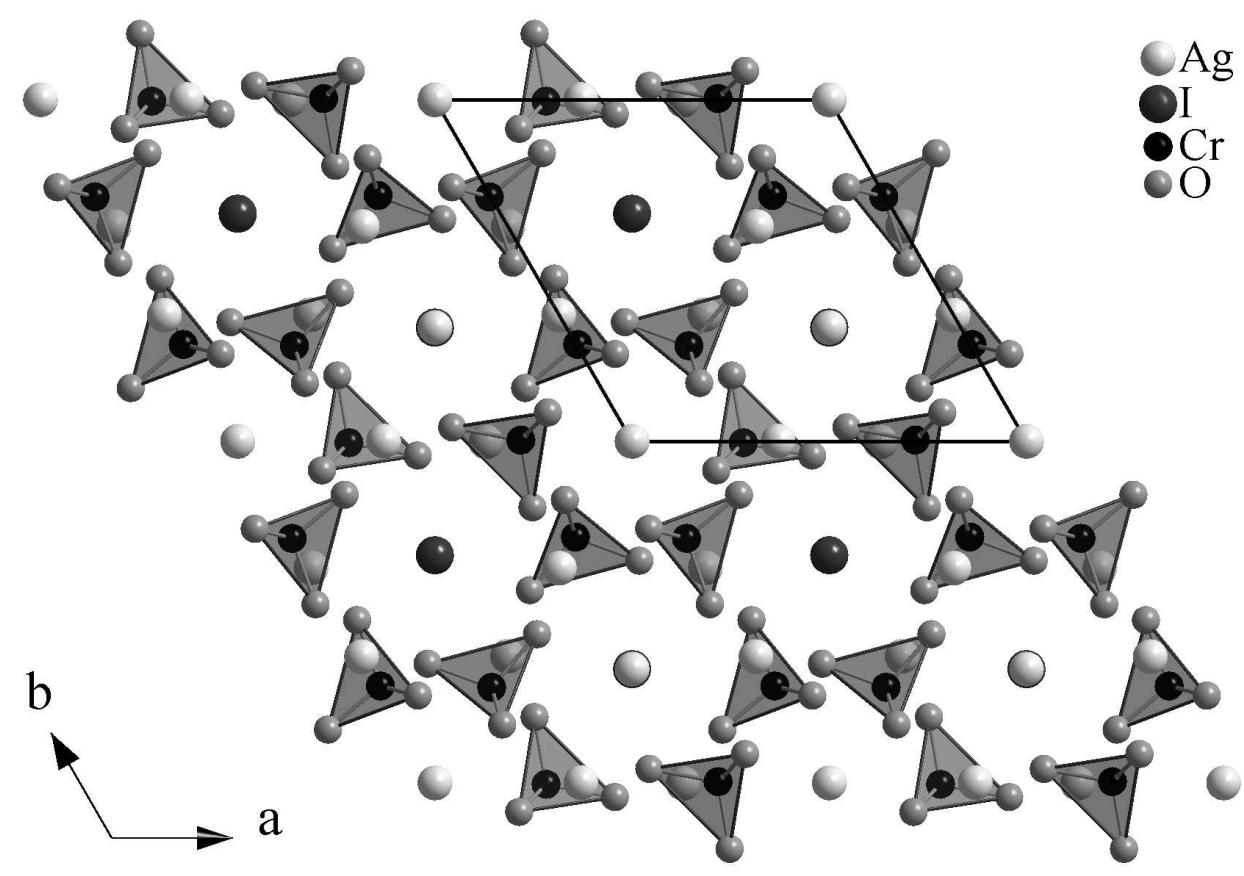

$468 \times 468 \mathrm{~mm}(96 \times 96$ DPI $)$

Wiley-VCH 


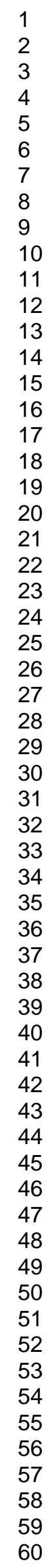
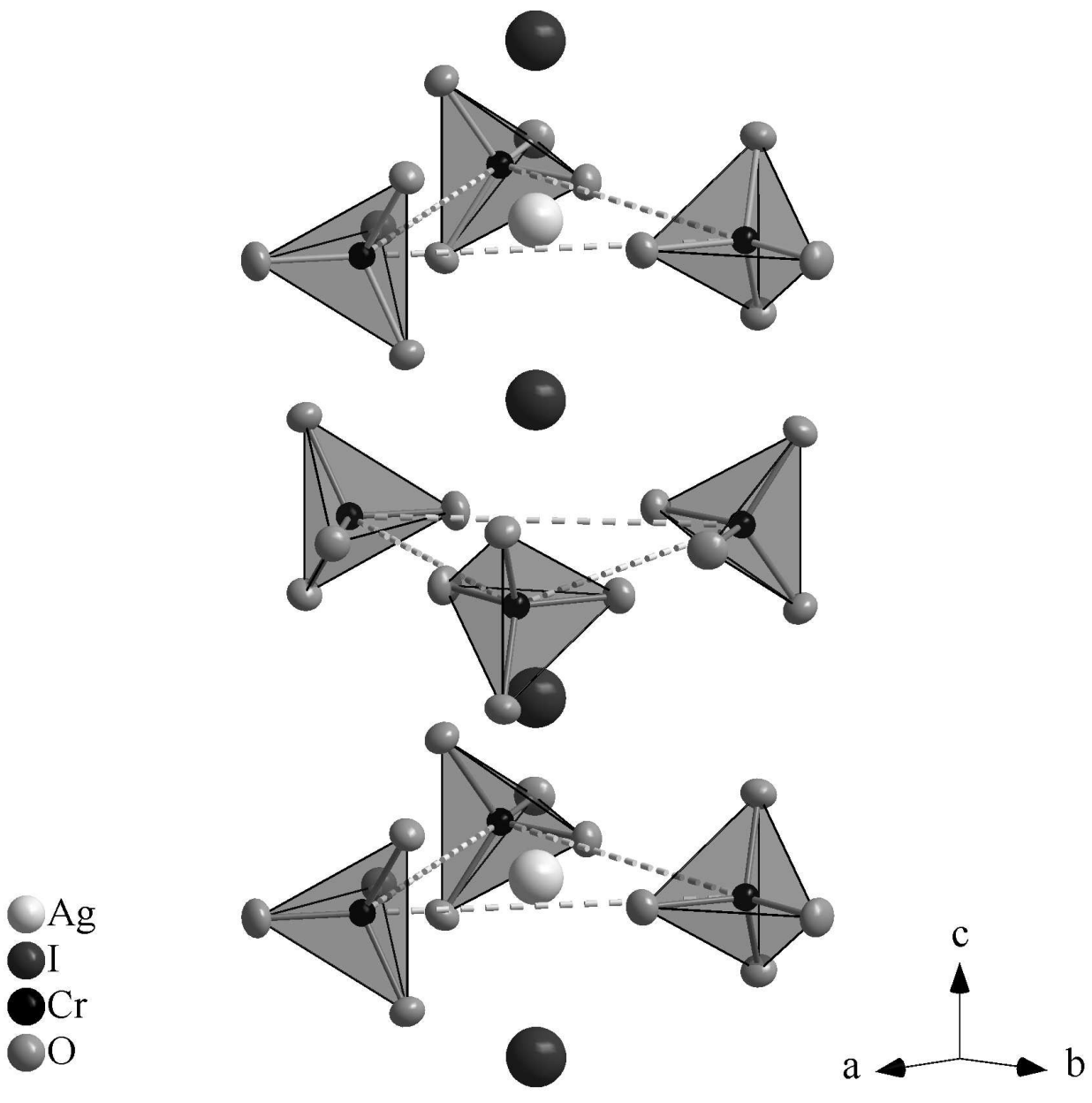

$468 \times 468 \mathrm{~mm}(96 \times 96 \mathrm{DPI})$

Wiley-VCH 
1

2

3

4

5

6

7

8

9

10

11

12

13

14

15

16

17

18

19

20

21

22

23

24

25

26

27

28

29

30

31

32

33

34

35

36

37

38

39

40

41

42

43

44

45

46

47

48

49

50

51

52

53

54

55

56

57

58

59

60

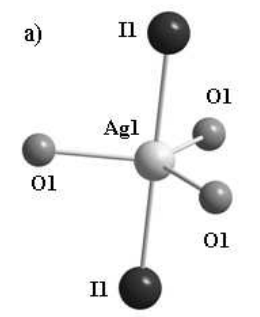

b)
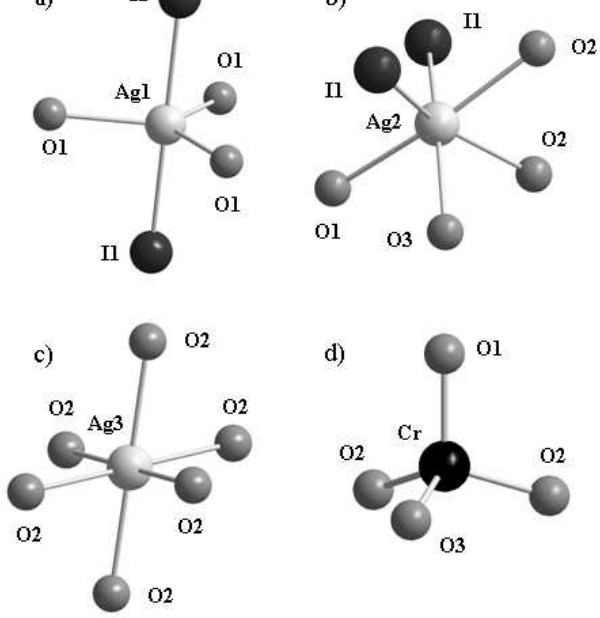

254x190mm (96 x 96 DPI) 


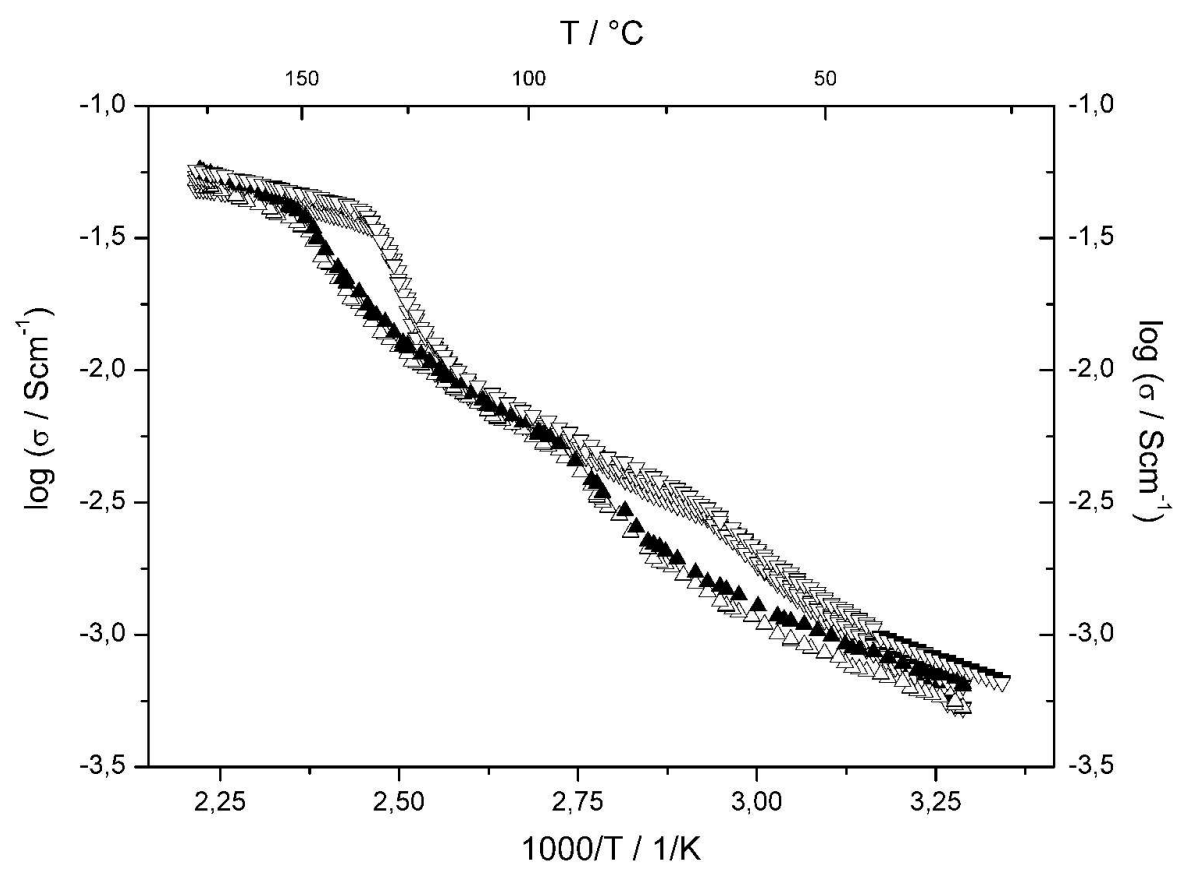

$282 \times 215 \mathrm{~mm}(600 \times 600 \mathrm{DPI})$ 